DR. JUANA M. PASQUINI (Orcid ID : 0000-0001-7683-0228)

Article type : Original Article

\title{
Extracellular vesicles containing the transferrin receptor as nanocarriers of apotransferrin
}

Mattera VS ${ }^{1}$, Pereyra Gerber $\mathrm{P}^{5}$, Glisoni $\mathrm{R}^{3,4}$, Ostrowski $\mathrm{M}^{5}$, Verstraeten $\mathrm{SV}^{1,2}$, Pasquini

$$
\mathrm{JM}^{1,2^{*}} \text {, Correale } \mathrm{JD}^{6^{*}} \text {. }
$$

${ }^{1}$ Universidad de Buenos Aires. CONICET. Instituto de Química y Fisicoquímica

Biológicas (IQUIFIB). Buenos Aires, Argentina.

${ }^{2}$ Universidad de Buenos Aires. Facultad de Farmacia y Bioquímica. Departamento de Química Biológica. Buenos Aires, Argentina.

${ }^{3}$ Universidad de Buenos Aires. Facultad de Farmacia y Bioquímica. Departamento de Tecnología Farmacéutica. Buenos Aires, Argentina.

${ }^{4}$ Universidad de Buenos Aires. CONICET. Instituto de Nanobiotecnología

(NANOBIOTEC). Buenos Aires, Argentina

${ }^{5}$ Universidad de Buenos Aires. CONICET. Instituto de Investigaciones Biomédicas en

Retrovirus y SIDA. Buenos Aires, Argentina.

${ }^{6}$ FLENI. Buenos Aires, Argentina.

*Both are senior authors in this paper

\section{Corresponding author:}

Juana María Pasquini

Instituto de Química y Fisicoquímica Biológicas (IQUIFIB). Buenos Aires, Argentina.

Junín 954, C1113AAD CABA

Phone number: $541149648287 / 88$

Email: jpasquin@qb.ffyb.uba.ar 
Secondary email: juanampasquini@gmail.com

Running title: Extracellular vesicles as nanocarriers of apotransferrin

Abbreviations: aTf, apotransferrin; CNS, central nervous system; DMEM, Dulbecco's modified Eagle's medium; FCS, fetal calf serum; OL, oligodendrocyte; OPC, oligodendrocyte progenitor cell; Tf receptor, TfR1; Tf-TR, Texas red-labeled Tf; RRID, research resource identifier.

Keywords: Extracellular vesicles, Transferrin, Transferrin receptor 1, Dynamic light scattering, Scanning electron microscopy, Size-exclusion chromatography. 


\begin{abstract}
Previous work by our group has shown the pro-differentiating effects of apotransferrin (aTf) on oligodendroglial cells in vivo and in vitro. Further studies showed the remyelinating effect of aTf in animal demyelination models such as hypoxia/ischemia, where the intranasal administration of human aTf provided brain neuroprotection and reduced white matter damage, neuronal loss and astrogliosis in different brain regions.
\end{abstract}

These data led us to search for a less invasive and controlled technique to deliver aTf to the CNS. To such end, we isolated extracellular vesicles (EVs) from human and mouse plasma and different neuron and glia conditioned media and characterized them based on their quality, quantity, identity and structural integrity by Western blot, dynamic light scattering and scanning electron microscopy. All sources yielded highly pure vesicles whose size and structures were in keeping with previous literary evidence. Given that, remarkably, EVs from all sources analyzed contained Tf receptor 1 (TfR1) in their composition, we employed two passive cargo-loading strategies which rendered successful EV loading with aTf, specifically through binding to TfR1.

These results unveil EVs as potential nanovehicles of aTf to be delivered into the CNS parenchyma, and pave the way for further studies into their possible clinical application in the treatment of demyelinating diseases. 


\section{Introduction}

Extracellular vesicles (EVs) are lipid bilayer-enclosed structures originated from the intracellular endocytic trafficking pathway or from the plasma membrane which are released into the extracellular space by a variety of cells (György et al., 2011; Harding et al., 1983; Pan et al., 1985). The lipid composition of EVs reveals enrichment in cholesterol, sphingomyelin and ganglioside GM3 levels (Wubbolts et al., 2003; Skotland et al., 2017). Furthermore, their membranes contain tetraspanin proteins, including CD63 -a protein accumulating in multivesicular bodies-, CD9/CD81 -mainly at the plasma membrane-, and endosome membrane proteins flotillin and ALIX, which have been used as EV markers (Park et al., 2010; Kowal et al., 2016). EVs can be secreted by most cell types in vitro and are detectable in different biological fluids such as blood (Harding et al., 1984; Sanz-Rubio et al., 2018), cerebrospinal fluid (CSF) (Soares Martins et al., 2018), breast milk (Zhou et al., 2011), urine (Keri et al., 2018; Hildonen et al., 2016) and plasma (Caby et al., 2005).

From a physiological point of view, EV secretion was initially postulated as a mechanism through which cells eliminate unnecessary proteins (Harding et al., 1983; Pan et al., 1985). However, studies indicate that EVs are actually involved in long-distance intercellular communication, facilitating the transfer of functional proteins, mRNAs and miRNAs for subsequent protein expression in target cells (Skog et al., 2008; Valadi 2007). Protection by a lipid bilayer lends EVs stability in the bloodstream and keeps the payload safe from the immune system. In addition, EV lipid membranes can help them bypass natural barriers such as the blood brain barrier (BBB) (Rajendran et al 2014; Basso et al., 2016). Altogether, these characteristics make EVs a valuable delivery system for pharmacological substances to address different central nervous system (CNS) diseases (Caruso Bavisotto et al., 2019).

EV isolation from biological fluids with good recovery and free of protein or lipoprotein contamination remains to be optimized. Although differential centrifugation and densitygradient ultracentrifugation are the most widely applied methods so far, protein aggregates are generated at high speed, and vesicles may thus clump (György B et al., 2011). Isolation of EVs is further hindered by plasma viscosity and density and by the presence of lipoproteins, therefore requiring longer ultracentrifugation times and higher speeds, which can further compromise exosome integrity (Théry et al., 2006; Van der Pol et al., 2012). 
Multiple alternative approaches have been developed to tackle these obstacles, among which the use of size exclusion chromatography (SEC) columns emerges as a suitable method to obtain clean EVs from supernatants or plasma. SEC is hence now recognized as the best method for separation of EVs from most, but not all, serum proteins (Hong et al 2016).

Apotransferrin (aTf) is the main $\mathrm{Fe}^{3+}$ transporter in the organism and is mostly expressed in the liver. In the CNS, aTf is produced by oligodendrocytes and is vital for normal brain development. Our group has previously demonstrated the pro-differentiating effects of aTf in vivo (Escobar Cabrera et al., 1994; Escobar Cabrera et al., 1997; Marta et al., 2000) as well as in vitro (Paez et al., 2002). We have also reported that a single intracranial injection of aTf stimulates remyelination after cuprizone-induced demyelination (Adamo et al., 2006) and prevents hypomyelination produced by iron deficiency (Rosato-Siri et al., 2010). Furthermore, using a hypoxic ischemic model in rats, we have shown that aTf injected intracranially reduces white matter injury (Guardia Clausi et al., 2010), while human aTf administered intranasally provides neuroprotection to neonate animals (Guardia Clausi et al., 2012).

The use of EVs with a clearly defined active therapeutic cargo such as aTf entails the need of a surface marker to ensure targeting at recipient cells. However, EV isolation as nanovehicles and their targeting at specific cell types affected in the CNS remain a challenge. Although shown to stimulate remyelination in animal models, intracerebral administration of aTf might not be adequate for clinical treatments. For these reasons, intranasal administration might be regarded as a highly promising non-invasive route for the treatment of chronic CNS disease, with several studies underscoring the potential of loaded EVs (Zhang et al., 2011; Haney et al., 2015; Long et al., 2017). Moreover, aTf encapsulation in EVs reduces potential immunogenicity, prevents its degradation by proteases and allows it to cross the BBB without serious systemic side effects. Therefore, the development of a minimally invasive technique to intranasally administer aTf-loaded EVs targeted at oligodendrocytes might prove to have clinical significance.

In this context, our work has focused on the isolation of EVs from plasma and different conditioned media, with special emphasis on those of human plasma. EV preparations were characterized in terms of identity, size, yield and structural integrity. The presence of the Tf 
receptor 1 (TfR1) in EVs isolated from different sources and the binding of aTf to its receptor make EVs suitable vehicles for aTf and paves the way for their use as nanocarriers of aTf in different demyelination models. 


\section{Materials and Methods}

\subsection{Ethics statement}

Experiments complied with the guidelines for animal use and care of Facultad de Farmacia y Bioquímica, Universidad de Buenos Aires, approved by Council Directive Res.250/2014. No randomization methods were applied. No blinding was performed. This study was not pre-registered. Sample size was determined using literary evidence in the field (ElAndaloussi et al., 2012; Haney et al., 2015; Böing et al., 2014; Théry et al., 2006)

\subsection{Materials and reagents}

Human aTf, poly-L-lysine and Sepharose CL-2B were obtained from Sigma-Aldrich (St Louis, MO, USA). Dulbecco's modified Eagle's medium (DMEM)/F12 and human transferrin conjugated to Texas red (Tf-TR) were purchased from Life Technologies (Buenos Aires, Argentina). Fetal calf serum (FCS) was obtained from Natocor (Córdoba, Argentina). Twelve mL cartridges were purchased from Applied Separations (Allentown, PA, USA), PVDF transfer membranes were from Millipore (Temecula, CA, USA), while ECL Plus Western Blotting Detection reagents were purchased from GE Healthcare (Buckinghamshire, UK). Antibodies used were as follows: mouse anti-Alix (RRID: AB_10899268), mouse anti-CD63 (ab213090), mouse anti-CD63 (ab193349) and rabbit anti-Calnexin (CNX) (RRID: AB_1310022) were purchased from Abcam (Cambridge, UK) chicken anti- seroTf (RRID: AB_1081485) was from Genetex (Irvine, California) while mouse anti-TFR1 (RRID: AB_86623) was obtained from Thermo Fischer Scientific (San Jose, CA, USA). Human anti Tf (RRID: AB_2287232) was from ICN Biomedicals (Cappel, Aurora, Ohio), Horseradish peroxidase-conjugated secondary antibodies used for immunoblotting were obtained from Jackson Immuno Research Laboratories (West Grove, PA, USA). All other chemicals were analytical grade reagents.

\subsection{Cells and plasma EVs sources}

The mouse cell line Neuro-2A (N2a) derived from a spontaneous neuroblastoma in A/J mice (ATCC; CCL-131), and the rat oligodendroglioma OLN-93 cell line (a generous gift

from Dr. C. Richter-Landsberg (Richter-Landsberg et al., 1995)), neither listed as a commonly misidentified cell line by the International Cell Line Authentication Committee, were cultured in DMEM/F12 (1:1 v/v) supplemented with 10\% (v/v) FCS, $5 \mathrm{mg} / \mathrm{mL}$ 
streptomycin and $5 \mathrm{U} / \mathrm{mL}$ penicillin at $37^{\circ} \mathrm{C}$ in a humidified atmosphere containing $5 \%$ $\mathrm{CO}_{2}$. The medium was replaced every 2 or 3 days until reaching $70 \%$ confluence.

The oligodendrocyte conditionally immortalized cell line N20.1, kindly provided by Dr. A.T. Campagnoni (Verity et al., 1993) and not listed as a commonly misidentified cell line by the International Cell Line Authentication Committee, was grown to confluence in DMEM/F12 with $10 \% \mathrm{FCS}$ at $34{ }^{\circ} \mathrm{C}$ (permissive temperature). The medium was replaced by DMEM/F12 with $1 \%$ FCS and the temperature shifted to $39{ }^{\circ} \mathrm{C}$ (non-permissive temperature) for 7 days. Cells were maintained up to 8 passages, cryopreserved regularly and authenticated according to ATTC recommended tests, through morphological observation on an optical microscope and Hoechst assays to control mycoplasma contamination.

Primary cultures of astrocytes from newborn P0-P3 Wistar rats (Jackson Laboratory, RRID: RGD_13508588) were performed according to McCarthy and de Vellis (McCarthy et al., 1980). Animals were decapitated with scissors and, after the removal of the meningeal membranes, cerebral hemispheres were mechanically dissociated by gentle repetitive pipetting in a mixture of DMEM/F12 (v/v) supplemented with 10\% FCS, $5 \mathrm{mg} / \mathrm{mL}$ streptomycin and $5 \mathrm{U} / \mathrm{mL}$ penicillin. The cell suspensions were seeded in poly-L-lysinecoated $75 \mathrm{~cm}^{2}$ tissue culture flasks and incubated at $37{ }^{\circ} \mathrm{C}$ in $5 \% \mathrm{CO}_{2}$, with medium changes every 3 days. After 14 days in culture and once cells reached confluence, the microglial subpopulation was discarded after a first shake at $140 \mathrm{rpm} / \mathrm{min}$ during $1 \mathrm{~h}$. The remaining culture was then shaken overnight at $250 \mathrm{rpm}$ at $37^{\circ} \mathrm{C}$, the suspended cells were discarded, and the remaining astrocytes were kept in DMEM/F12 with 1\% FCS.

Human and mouse plasma were obtained from blood samples from healthy donors recruited from the lab personnel ( $\mathrm{n}=5$; both genders; age: 25-35 years; BMI: $24-33)$, or mouse (25$40 \mathrm{~g}$; 45-50 days old) obtained from Jackson Laboratory (RRID: MGI:5656552), and collected into tubes containing citrate dextrose solution (BD Biosciences Pharmingen, San Diego, CA, USA). Plasma was obtained by two centrifugation cycles at 3,000 $x \mathrm{~g}$ for 10 min at $4{ }^{\circ} \mathrm{C}$, keeping in both cases the supernatants. For plasma EV isolation a total of 20 adult mice were used. For primary culture 10 P0-P3 rats were used.

Animals were maintained in transparent plastic cages with a maximum of 5 animals per cage, with access to drinkable water ad libitum. Watering devices, such as drinking tubes 
and automated water delivery systems, were checked frequently to ensure appropriate maintenance, cleanliness and operation.

\subsection{Isolation of EVs from blood plasma with size-exclusion chromatography (SEC)}

SEC was performed as described previously (Böing et al., 2014). Two mL of human or mouse plasma were loaded into gravity-eluted columns of $12 \mathrm{~mL}$ cartridges containing Sepharose CL-2B matrix and fractions were eluted with degassed PBS:citrate $0.32 \%$. The first 4 fractions of $1 \mathrm{~mL}$ were collected, pooled and ultracentrifuged at 100,000 $\times \mathrm{g}$ for 70 min at $4{ }^{\circ} \mathrm{C}$. The resulting pellets were lysed with RIPA extraction buffer $(\mathrm{NaCl} 150 \mathrm{mM}$, EDTA $5 \mathrm{mM}$, Tris $50 \mathrm{mM}$, NP-40 1\%, SDS 0.1\%) supplemented with a protease inhibitor cocktail for $5 \mathrm{~min}$ on ice or in PBS, depending on the assay. Additionally, a dilution of plasma sample in RIPA buffer was prepared at the same time and used in parallel with EVs as control for immunoblot analysis.

\subsection{Isolation of EVs from conditioned media by differential centrifugation}

Following the different cell culture conditions previously described, N2a, N20.1, OLN-93 cells and astrocytes from primary cultures were grown to $70 \%$ confluence, washed twice with PBS and replaced with serum-free medium for 24-72 h. The conditioned media were collected and centrifuged during $10 \mathrm{~min}$ at $300 \times g$ in order to remove the remaining cells. The supernatants were then subjected to $2,000 \times \mathrm{g}$ centrifugation to remove dead cells. The resulting supernatants were collected and centrifuged at $10,000 \times g$ for 30 min at $4{ }^{\circ} \mathrm{C}$ in order to pellet the cell debris and organelles. Finally, the supernatants were again subjected to high speed centrifugation at $100,000 \times \mathrm{g}$ for $70 \mathrm{~min}$ at $4{ }^{\circ} \mathrm{C}$ to pellet EVs. The pellet was washed with $1 \mathrm{~mL}$ PBS to eliminate the contaminating proteins and ultracentrifuged again at $100,000 \times \mathrm{g}$ for $70 \mathrm{~min}$ at $4{ }^{\circ} \mathrm{C}$. In all cases the resulting pellet were lysed with RIPA extraction buffer supplemented with a protease inhibitor cocktail for $5 \mathrm{~min}$ on ice or in sterile PBS, depending on the assay. Additionally, cellular lysates were prepared at the same time and used in parallel with EVs as control for immunoblot analysis.

\subsection{Immunoblot analysis}

EVs obtained from conditioned media were harvested in $100 \mu \mathrm{L}$ of ice cold lysis buffer (20 mmol/L Tris-HCl (pH: 8), 1\% Nonidet P-40, 10\% glycerol, 137 mmol/L NaCl, $1 \mathrm{mmol} / \mathrm{L}$ 
PMSF, $1 \mathrm{mmol} / \mathrm{L}$ aprotinin, $0.1 \mathrm{mmol} / \mathrm{L}$ sodium vanadate, and $20 \mathrm{mmol} / \mathrm{L}$ of sodium fluoride). Protein content in EV samples and cell lysates was determined by Pierce BCA Protein Assay Kit (Life Technologies), and the samples were adjusted with loading buffer containing $2 \%$ sodium dodecyl sulfate (SDS), 5\% glycerol, 5\% $\beta$-mercaptoethanol and $0.01 \%$ bromophenol blue, boiled for $5 \mathrm{~min}$. Aliquots containing $20 \mu \mathrm{g}-40 \mu \mathrm{g}$ protein were resolved by 10\% SDS polyacrylamide gel electrophoresis (SDS-PAGE) and transferred onto PVDF membranes. Membranes were blocked with 5\% non-fat dried milk in $0.1 \%$ Tween 20 in TBS for $1 \mathrm{~h}$ at room temperature and incubated with an appropriate primary antibody overnight at $4{ }^{\circ} \mathrm{C}$ (CD63 1:600; Alix 1:1000; TfR1 1:1000; Tf 1:1000; CNX 1:1000). After being washed 3 times for 10 min with TBS Tween $0.1 \%$, membranes were incubated with the corresponding secondary antibodies (1:20000), and bands were visualized by Pierce ${ }^{\mathrm{TM}}$ ECL Western Blotting Substrate (Thermofisher, Waltham, MA, USA).

\subsection{Size and size distribution analysis}

The average size (Z-average), the hydrodynamic diameter $\left(\mathrm{D}_{h}\right)$, the size distribution (polydispersity index, PDI) and zeta potential (Z-potential) of different EV sources were assayed by dynamic light scattering (DLS, Zetasizer Nano-ZS, Malvern Instruments, Worcestershire, UK) at a scattering angle of $173^{\circ}$. The Nano-ZS contains a $4 \mathrm{~mW}$ He-Ne laser operating at a wavelength of 633 nm, a digital correlator ZEN3600 and Non-Invasive Back Scatter (NIBS $®)$ technology. For the preparation of each EV sample, $1 \mathrm{~mL}$ plasma was isolated and resuspended in $10 \mu \mathrm{L}$ of the original fresh sample and then diluted to $1000 \mu \mathrm{L}$ of final volume using PBS (1:100). All the samples were analyzed at 4 and $25^{\circ} \mathrm{C}$. Refractive index (RI) was 1.48 and viscosities between 1.568 and $1.572 \mathrm{cP}\left(4{ }^{\circ} \mathrm{C}\right)$ and 0.8866 and 0.8885 $\mathrm{cP}\left(25^{\circ} \mathrm{C}\right)$. Results are expressed as mean \pm S.D. of three independent samples prepared in identical conditions. Data for each single specimen were the result of at least six runs.

\subsection{Scanning electron microscopy (SEM)}

After the first ultracentrifugation step, the pellets of all samples were fixed in $50 \mu l$ paraformaldehyde (PFA) $4 \%$ for $15 \mathrm{~min}$ at $4{ }^{\circ} \mathrm{C}$. The solution was then washed with $1 \mathrm{~mL}$ Milli- $Q$ water and ultracentrifuged at $100,000 \times \mathrm{g}$ for $70 \mathrm{~min}$ at $4{ }^{\circ} \mathrm{C}$, and the resulting pellet was resuspended in $50 \mu \mathrm{L}$ of Milli- $Q$ water. Twenty $\mu \mathrm{L}$ of fresh samples were put on a silica 
substrate, dried, metalized and observed with a Zeiss Supra Electron microscope. Six fields per experimental $\mathrm{n}$ were chosen randomly and EV size was determined using ImageJ software, first calculating the area of each individual EV to obtain the diameter.

\subsection{Loading of aTf into EVS}

Molecules can be incorporated into EVs using different approaches that result in different loading efficiency and molecule stability (Luan et al., 2017).

\subsubsection{Passive loading of aTf into human plasma EVS}

For aTf loading into human plasma EVs, we first verified the presence of TfR1 in EVs. Upon detection of TfR1, EVs isolated from $2 \mathrm{~mL}$ of human plasma isolated by SEC were incubated with $100 \mu \mathrm{g} / \mathrm{mL}$ aTf overnight at room temperature and loading efficiency was evaluated by Western blot and fluorometry.

\subsubsection{Passive loading of aTf into OLN93 EVS}

To obtain aTf-loaded EVs, when the cells reached $70 \%$ confluence, the medium was depleted from FCS and cells were treated with either vehicle or $100 \mu \mathrm{g} / \mathrm{mL}$ of aTf for $30 \mathrm{~min}$, which is the time when Tf reaches its maximum cytoplasmic concentration (Böing et al., 2013). Subsequently, 48-72 h later, culture media were collected and EVs were isolated by differential centrifugation and ultracentrifugation methods.

\subsection{Ligand-binding assays of EV-TfRI-Tf}

\subsubsection{Competition assays}

Competition assay I: EV samples obtained from $2 \mathrm{~mL}$ plasma (yielding $\sim 60 \mu \mathrm{g}$ protein) and isolated by SEC as described above were resuspended in PBS or $100 \mu \mathrm{g} / \mathrm{mL}$ Tf-TR and incubated overnight with continuous shaking at room temperature. The incubated samples were ultracentrifuged twice at $100,000 \times \mathrm{g}$ during $70 \mathrm{~min}$ at $4{ }^{\circ} \mathrm{C}$ to eliminate non-bound fluorescent protein and supernatant samples were also collected. Aliquots of samples incubated with Tf-TR were incubated with a high concentration of $400 \mu \mathrm{g} / \mathrm{mL}$ nonfluorescent human aTf overnight with continuous shaking at room temperature. After incubation, samples were ultracentrifuged twice again and a supernatant sample was collected. The remaining pellet was resuspended in RIPA and fluorescence was measured in a Perkin Elmer LS55 fluorometer (Perkin Elmer Ltd, Beaconsfield, UK). 
Competition assay II: EV samples obtained from $2 \mathrm{~mL}$ plasma per condition and isolated by SEC as described above were resuspended in PBS or $400 \mu \mathrm{g} / \mathrm{mL}$ both native and denatured Tf and incubated overnight with continuous shaking at room temperature. The incubated samples were ultracentrifuged twice at $100,000 \times \mathrm{g}$ during $70 \mathrm{~min}$ at $4{ }^{\circ} \mathrm{C}$ to eliminate non-bound protein and supernatant samples were also collected. Aliquots of samples incubated with $\mathrm{Tf}$ were incubated with a low-concentration of $100 \mu \mathrm{g} / \mathrm{mL}$ Tf-TR overnight with continuous shaking at room temperature. After incubation, samples were ultracentrifuged twice again and the supernatant sample was collected. The remaining pellet was resuspended in RIPA and fluorescence was measured in a Perkin Elmer LS55 fluorometer (Perkin Elmer Ltd.).

\subsubsection{Incubation of EVs with different Tf-TR concentrations}

EV samples obtained from $2 \mathrm{~mL}$ plasma per condition and isolated by SEC as described above were resuspended in PBS, different Tf-TR concentrations $(10,20,100,200 \mu \mathrm{g} / \mathrm{mL})$ and incubated overnight with continuous shaking at room temperature. The incubated samples were ultracentrifuged twice at 100,000 $\times \mathrm{g}$ during $70 \mathrm{~min}$ at $4{ }^{\circ} \mathrm{C}$ to eliminate nonbound protein and supernatant samples were also collected. The remaining pellet was resuspended in RIPA and fluorescence was measured in a Perkin Elmer LS55 fluorometer (Perkin Elmer Ltd.).

\subsubsection{Incubation of TF-TR with different amounts of EVS}

EV samples obtained from $2 \mathrm{~mL}$ plasma per condition were isolated by SEC as described above. Different amounts of EVs $(30,60,90,120 \mu \mathrm{g})$ were resuspended in PBS or 100 $\mu \mathrm{g} / \mathrm{mL}$ Tf-TR overnight with continuous shaking at room temperature. The incubated samples were ultracentrifuged twice at $100,000 \times \mathrm{g}$ during $70 \mathrm{~min}$ at $4{ }^{\circ} \mathrm{C}$ to eliminate nonbound fluorescent protein and supernatant samples were also collected. The remaining pellet was resuspended in RIPA and fluorescence was measured in a Perkin Elmer LS55 fluorometer (Perkin Elmer Ltd.).

\subsection{Statistical analysis}

Graph-Pad Prism 7 software was used for data analysis. Results are presented as the mean of at least three independent EV isolation experiments \pm standard error of the mean (SEM). Normality of data was evaluated using Shapiro-Wilk normality test. No data points were excluded from the analysis. Comparisons were performed using unpaired one tailed Student's

$t$ test and one-way analysis of variance (ANOVA) followed by Bonferroni post-hoc tests, where appropriate. A P value under 0.05 was considered statistically significant. 


\section{Results}

Isolation and characterization of EVs from plasma, cell lines and cell culture isolated cells

Using different strategies, we characterized EVs isolated from both human and mouse fluids and different conditioned media. The main objective of the isolation and characterization process was to obtain EVs which function properly as nanovehicles, focusing on EV identity, yields, quality, purity and structural integrity.

For the isolation of fluids, protocols based on differential centrifugation can result in the co-isolation of complexes associated with non-vesicular materials. In order to overcome this obstacle, we isolated vesicles from plasma using SEC in order to efficiently separate the vesicular fractions from the protein fractions. The amount of protein from the plasma fractions measured and each fraction was analyzed by Western blot to detect the typical CD63 marker of the vesicular route (Fig 1A).

We found that fractions 2-4 expressed CD63 and succeeded in separating the vesicular fraction from protein content, especially albumin. For all sources, we determined the identity of the vesicles by Western blot (Fig 1B) using the Alix endosomal pathway marker and observed a significant enrichment in the vesicular fractions with respect to plasma or the respective cell lysates of each source. Particularly, in EVs from in vitro secretory cells, the level of Alix enrichment was high. Simultaneously, we conducted analyses of proteins which should be absent in EVs and which are associated with compartments other than plasma membrane or endosomes, such as the intracellular endoplasmic protein CNX. The presence of $\mathrm{CNX}$ in the EV fraction is also an indicator of cell lysis, a condition in which EVs should not be isolated not only because of the contaminating components from other intracellular compartments, but also because of the physiological state of the cells. In this sense, we observed the absence of CNX in the fractions corresponding to the EVs.

It should be highlighted that, when cultured with DMEM/F12 with FCS without EVs, N20.1 cells were non-viable either at proliferating or differentiating temperatures. Moreover, EV depletion from FCS affected cell phenotype and viability especially when cells were grown at a non-permissive $39{ }^{\circ} \mathrm{C}$, which indicates that serum EVs contain fundamental information for the development of this cell line (data not shown). Further experiments will be done in the future in order to clarify this point. 
In addition, the amount of EVs produced can vary significantly depending on cell types and physiological state. In the current work, the yield of EV as total protein content obtained from the different cell lines was significantly larger than that of astrocyte cultures. Human and mouse plasma yielded similar amounts of EVs, in both cases higher than those obtained from cell lines (Table I).

We also confirmed the quality, purity and integrity of the samples through DLS and SEM. Worth pointing out, factors such as EV dilution of work and temperature can critically affect their quality as nanovehicles. On the one hand, at high concentrations and at temperatures over $4{ }^{\circ} \mathrm{C}$, EVs tended to agglomerate and became difficult to handle. On the other hand, frozen samples stored at $-80{ }^{\circ} \mathrm{C}$ for more than 6 months and then thawed rendered measurements outside the expected EV hydrodynamic diameter, which indicates possible breakage and agglomeration due to the freezing and thawing processes (data not shown). In contrast, freshly isolated EVs displayed lower Z-average sizes at $4{ }^{\circ} \mathrm{C}(115-211 \mathrm{~nm})$ than at $25^{\circ} \mathrm{C}(161-374 \mathrm{~nm})$ in all cases, a tendency replicated by $\mathrm{D}_{h}$. The PDI values were found to be between 0.237 and 0.381 for monomodal EVs and between 0.427 and 0.554 for bimodal samples at $25{ }^{\circ} \mathrm{C}$. Also, monomodal size distribution indicated the existence of a single population in the range of sizes expected for EVs, thus ruling out the presence of contaminating residues from the isolation process or EV agglomeration. Moreover, Z-average sizes for Tf-free EVs and Tf-loaded EVs derived from human plasma were 161 and $267 \mathrm{~nm}$ at $25{ }^{\circ} \mathrm{C}$, respectively. Worth highlighting, Tf incorporation on the surface of EVs did not significantly affect the range of sizes found for EVs and actually rendered a lower negative Zpotential $(-36 \mathrm{mV})$ than Tf-free EVs $(-27 \mathrm{mV})$. The average Z-potential of free $\mathrm{Tf}$ at a charge concentration identical to that used for the formation of Tf-loaded EVs was approximately -14 $( \pm 2) \mathrm{mV}$ (Table II and IV and Fig 2).

Finally, SEM revealed uncompromised integrity of the vesicle structures obtained through the two isolation methods and determined the heterogeneity of EV sizes within each source and their average (Fig 3). Of note, even though the EV sources used in this study are morphologically heterogeneous, their EVs had comparable sizes and shapes (Fig 3).

Altogether, these results confirm the successful isolation of EVs from very different and complex sources and their features in terms of identity and integrity to function as suitable nanovehicles. 


\section{EV expression of TfR 1 and loading with aTf}

Previous studies demonstrated that TfR1 is released in association to vesicles (Pan et al., 1983). Indeed, electron microscopic studies have shown that endocytosis of TfR1 is followed by the formation of multivesicular bodies which, upon fusion with the plasma membrane, release $50 \mathrm{~nm}$ buds into the extracellular milieu. TfR1 released in vesicular form is apparently unchanged in its molecular weight, peptide sequence and capacity for aTf binding (Pan et al., 1985). In agreement with this evidence, all EVs isolated from different conditioned media in the current study showed the presence of TfR1 (Fig 4 and Table III), which exhibited $90 \mathrm{kDa}$, the size expected for an intact, still membraneassociated monomer. In addition, immunoblotting assays on $1 \mathrm{~mL}$ fractions obtained from SEC confirmed TfR1 association to EVs, in agreement with the colocalization of CD63 and TfR1 in fractions 2-4 (Fig 1A).

Based on these findings, we analyzed the ability of EVs to load our protein of interest, aTf. Western blot analyses revealed aTf presence both in EVs isolated from human plasma incubated with aTf and in those secreted by aTf-treated OLN-93 cells, while no aTf expression was observed in control human plasma EVs or in vehicle-treated cells (Fig. 4A and B).

In turn, EVs incubation with Tf-TR showed higher fluorescence intensity than controls and rendered around $330 \mathrm{ng} / \mathrm{mg}$ EVs. In contrast, EV-free PBS incubated with Tf-TR and subsequently processed as EV-containing samples exhibited no fluorescence, which indicates that $\mathrm{Tf}$ binding requires the presence of EVs. These results, obtained by means of two different methodologies, indicate that EVs isolated from different sources were able to bind aTf (Fig 4C).

Two different competition assays were conducted to determine whether the binding of $\mathrm{Tf}$ to EVs proceeded through its interaction with TfR1 located at the extraluminal phase of the EVs and also whether this interaction was specifically due to the binding of Tf-TR to TfR1. In the first competition assay, EVs showed lower fluorescence intensity values, indicating that bound Tf-TR was displaced by the excess of non-labeled Tf. The low remnant signal detected may indicate a minimal diffusion into EVs along the concentration gradient (Fig 5A, B). The second competition assay showed that saturating concentrations of native nonlabeled aTf occupied all TfR1 binding sites in the EVs, whereas subsequent incubation with low concentrations of labelled Tf-TR rendered no fluorescence signal regarding controls. In 
turn, saturating concentrations of denatured non-labeled aTf followed by incubation with low concentrations of labeled Tf-TR did reveal fluorescence signal regarding controls. These findings indicate that the loading of Tf into EVs occurred through the specific binding of Tf-TR to its receptor TfR1 in the extraluminal phase of EVs (Fig 5C, D). In addition, when the amount of EVs in the samples varied between 30 and $120 \mu \mathrm{g}$, the amount of Tf-TR remained fairly constant, as indicated by the similarity of EV fluorescence across samples. Moreover, when the concentration of Tf-TR in the samples varied but the amount of EVs in the samples was kept constant, the fluorescence ratio also remained constant (Fig 5E, F). 


\section{Discussion}

Tf is a glycoprotein synthesized mostly in the liver. The main function of $\mathrm{Tf}$ is to capture $\mathrm{Fe}^{3+}$ released into plasma from intestinal enterocytes or reticuloendothelial macrophages, maintain $\mathrm{Fe}^{3+}$ in a redox-inert state, and deliver it into tissues (Anderson et al., 2009). The binding of iron-laden Tf to cell-surface TfR 1 results in endocytosis and uptake of the metal cargo. In the CNS, most Tf is synthesized endogenously by oligodendrocytes and choroid plexus cells, and it is required for iron mobilization within the brain parenchyma and CSF (Espinosa de los Monteros et al., 1988). In our laboratory, we have demonstrated that aTf can increase cell proliferation in the subventricular zone and promote oligodendrocyte lineage commitment and terminal maturation (Silvestroff et al., 2012). Furthermore, we also reported that a single intracranial injection of aTf prevents hypomyelination produced by iron deficiency in rats (Badaracco et al., 2008). Collectively, these findings allowed us to define aTf as a trophic factor for the CNS. However, the intracranial injection of aTf might not be practical for clinical treatments, a drawback which requires the development of less invasive techniques capable of delivering aTf to the CNS.

In this sense, the intranasal route emerges as a promising non-invasive way to deliver molecules to the brain as it has many advantages from a clinical point of view; that is, molecules at biologically effective concentrations or even living cells can bypass the BBB and enter the CNS directly, avoiding hepatic and intestinal metabolism without serious systemic side effects (Thorne et al., 2001; Merkus et al., 2007; Danielyan et al., 2009). We have demonstrated in a rat model of hypoxia-ischemia encephalopathy that intranasally administered radio-labeled aTf can reach distant areas of the CNS, decreasing astrogliosis and neuronal loss, and promoting the survival and maturation of oligodendroglial precursors after demyelination (Guardia Clausi et al., 2012), which suggests intranasal aTf potential to induce remyelination.

EVs have recently risen to stardom as an excellent delivery system due to their distribution over long distances, long circulation half-life and reduced toxicity (Mathieu et al., 2011; Lai et al., 2013; Tan et al., 2013). Several features place EVs as potentially powerful shuttles for the delivery of therapeutic agents to the brain (Aryani et al., 2016). EVs loaded with antioxidant catalase given by intranasal administration have provided significant neuroprotection in an animal model of Parkinson's disease (Luan et al., 2017). Similarly, curcumin-loaded EVs have 
also been administered intranasally in mice, decreasing LPS-induced brain inflammation (Zhuang et al., 2011).

Although EVs show several advantages over other nanoparticle systems for carrying therapeutically active molecules, particularly polymer-based nanoparticles and lipid-based systems (Rufino-Ramos et al., 2017), EV isolation and purification methods still pose a challenge and should be improved to render higher yields, which will allow large-scale production and wide-spread use in clinical practice.

In this study, we isolated and properly characterized EVs from human and mouse plasma, rat oligodendroglioma cells OLN93, mouse neuroblastoma cells N2a and rat astrocytes in primary cultures, all of them expressing TfR 1 and thus potentially capable of delivering aTf to the CNS. TfR1 plays a central role in the transport of iron from the iron-Tf complex into the cell, which makes it ubiquitous in growing cells owing presumably to iron requirements for proliferation (Wang et al., 2011). There is general agreement that TfR1 undergoes internalization during iron delivery, and that $\mathrm{Tf}$ and its receptor are recycled back to the plasma membrane without degradation during many delivery cycles (Mellman et al., 1996). Furthermore, TfR1 is externalized by evagination of the plasma membrane in the form of EVs (Pan et al., 1983). Although studies in analog human cell lines had reported the presence of TfR1 in neuroblastoma- and astrocytoma-derived EVs (Marimpietri et al., 2013; Choi et al., 2018), in this work we demonstrate for the first time the expression of TfR 1 in EVs derived from OLN93, N2a cells and astrocytes.

EV yields depend on cell types and lines. Primary cultures are known to secrete fewer EVs than cell lines (Taylor et al., 2008; Logozzi et al., 2009), though the reason for this is not fully understood. We found that OLN93 and N2a cells rendered EV yields similar to those reported by El-Andaloussi et al. (El-Andaloussi et al., 2012) in HEK cells, and significantly higher than astrocyte cultures. This is in agreement with the fact that normal cells usually secrete fewer signal molecules through their vesicles than transformed cells. Plasma, on the other hand, yielded the largest amount of EVs, probably due to the contribution of other circulating cell types.

In agreement with literary evidence (Park et al., 2010), EV samples revealed the expression of characteristic proteins tetraspanin CD63 and intraluminal protein Alix and, as expected, showed the absence of endoplasmic reticulum protein CNX. In addition, EV Z-average sizes and $\mathrm{D}_{h}$ were also consistent with previous findings (Sokolova et al., 2011). 
In turn, PDI is an indicator of the degree of aggregation and size distribution of samples and is usually acceptable below 0.5 . In this sense, PDI values were acceptable for all monomodal samples and their ranges were consistent with those previously reported by other authors (Sokolova et al., 2011). In addition, the size distribution analyzed was within the range expected for EVs from other sources, and larger EVs were not visualized. However, we detected smaller vesicles, especially when EVs were obtained from cell lines, which were probably cell-released ectosomes. This result indicates that both methods of isolation yielded EVs matching the EV size range and lacking significant impurities associated to larger EVs. Z-potential is an estimation of surface charge registered for unloaded or loaded nanoparticles, and it is usually a predictive tool of colloidal stability at $25{ }^{\circ} \mathrm{C}$. Nanoparticles with Z-potential values greater than $+25 \mathrm{mV}$ or less than $-25 \mathrm{mV}$ typically have high degrees of stability, whereas dispersions with a low Z-potential absolute value and close to neutrality will eventually aggregate due to Van Der Waal interparticle attractions (Blachman et al., 2020). In this context, the fact that $\mathrm{Tf}$ incorporation did not significantly affect the range of EV sizes and even displayed a lower negative average Z-potential than that of Tf-free EVs suggests, first, the successful surface modification of these vesicles with $\mathrm{Tf}$ and, second, the great stability of this system as a potential biological nanocarrier.

SEM in turn revealed the structural integrity of EVs but also the size heterogeneity of each population and the purity obtained by both methods. First, the spherical morphology of EVs reflected their structural integrity and sizes were moderately smaller than those determined by DLS, especially for astrocytes and mouse plasma sources. These findings suggest changes in contraction patterns during sample preparations for SEM, while hydration sphere phenomena should not be ruled out for samples determined by DLS (Sokolova et al., 2011). Overall, this set of biochemical and biophysical properties will allow to attribute cargo-loading functions to EVs isolated from different sources.

Regarding the route underlying Tf binding, competition assays were carried out on the basis of the following hypothesis: if binding is non-specific to TfR1, both native and denatured protein will be adsorbed nonspecifically by the vesicular surface; on the other hand, if $\mathrm{Tf}$ binding is specific to TfR1, native Tf will saturate all TfR1 binding sites and will not be displaced upon incubation with Tf-TR at lower concentrations, whereas denatured Tf, in lacking the threedimension conformation necessary to bind to the receptor and thus being unable to compete with Tf-TR, will indeed be displaced. 
Most interestingly, these assays allowed to verify that a) $\mathrm{Tf}$ binding took place in the extraluminal phase of EVs, b) Tf was incorporated into EVs specifically through binding to TfR1, and c) all Tf binding sites were occupied upon EV incubation.

Altogether, the results obtained suggest that EVs isolated from different sources containing TfR1 can incorporate $\mathrm{Tf}$ by two distinct approaches of passive loading. To sum up, EVs have become increasingly relevant due to their function in intercellular communication and a wide range of physiological, pathological and therapeutic roles. Although further studies are in progress to track Tf-loaded EVs and ultimately determine whether they reach oligodendroglial cells in a demyelinating model, the current results pave the way for their potential clinical use as oligodendrocyte-targeted $\mathrm{Tf}$ nanovehicles to favor remyelination. 
--Human subjects --

Involves human subjects:

If yes: Informed consent \& ethics approval achieved:

=> if yes, please ensure that the info "Informed consent was achieved for all subjects, and the experiments were approved by the local ethics committee." is included in the Methods.

\section{--Acknowledgments--}

This work was funded by Agencia Nacional de Promoción Científica y Tecnológica, (Grant / Award Number: 'PICT 01798-2018') (grant number ): This information is usually included already, but please add to the Acknowledgments if not.

ARRIVE guidelines have been followed:

Yes

$=>$ if it is a Review or Editorial, skip complete sentence $=>$ if No, include a statement in the "Conflict of interest disclosure" section: "ARRIVE guidelines were not followed for the following reason:

II

(edit phrasing to form a complete sentence as necessary).

$\Rightarrow>$ if Yes, insert in the "Conflict of interest disclosure" section:

"All experiments were conducted in compliance with the ARRIVE guidelines." unless it is a Review or Editorial

Conflicts of interest: None

=> if 'none', insert "The authors have no conflict of interest to declare."

$\Rightarrow>$ otherwise insert info unless it is already included

\section{REFERENCES}

Adamo AM, Paez PM, Escobar Cabrera OE, Wolfson M, Franco PG, PasquiniJM,Soto EF. (2006) Remyelination after cuprizone-induced demyelination in the rat is stimulated by apotransferrin. ExpNeurol. 198:519-29.

Anderson GJ , Vulpe CD. (2009) Mammalian iron transport. Cell Mol Life Sci. 66: 3241 - 61. 
Aryani, A., \& Denecke, B. (2016) Exosomes as a Nanodelivery System: a Key to the Future of Neuromedicine? Molecular neurobiology, 53(2), 818-834. doi:10.1007/s12035-0149054-5.

Badaracco ME, Ortiz EH, Soto EF, Connor J, Pasquini JM.(2008) Effect of transferrin on hypomyelination induced by iron deficiency. J Neurosci Res. 86:2663-2673.23

Basso M, Bonetto V. (2016) Extracellular Vesicles and a Novel Form of Communication in the Brain. FrontNeurosci. 10:127. doi: 10.3389/fnins.2016.00127. eCollection2016.

Blachman, Funez, M. Birocco, Saavedra, Lázaro-Martinez, Camperi, Glisoni, Sosnik, Calabrese. (2020) Targeted anti-inflammatory peptide delivery in injured endothelial cells using dermatan sulfate/chitosan nanomaterials. Carbohydrate Polymers 230: 115610. doi: 10.1016/j.carbpol.2019.115610.

Böing AN, Stap J, Hau CM, Afink GB, Ris-Stalpers C, Reits EA, Sturk A, van Noorden CJ, Nieuwland R. (2013) Active caspase-3 is removed from cells by release of caspase-3enriched vesicles. BiochimBiophysActa. 1833(8):1844-52.

Böing, A. N., van der Pol, E., Grootemaat, A. E., Coumans, F. A., Sturk, A., \& Nieuwland, R. (2014) Single-step isolation of extracellular vesicles by size-exclusion chromatography. Journal of extracellular vesicles, 3, 10.3402/jev.v3.23430. doi:10.3402/jev.v3.23430

Caruso Bavisotto, C., Scalia, F., Marino Gammazza, A., Carlisi, D., Bucchieri, F., Conway de Macario, Campanella, C. (2019) Extracellular Vesicle-Mediated Cell-Cell Communication in the Nervous System: Focus on Neurological Diseases. International journal of molecular sciences. 20(2), 434. doi:10.3390/ijms20020434

Danielyan L, Schäfer R, von Ameln-Mayerhofer A, Buadze M, Geisler J, Klopfer T, Burkhardt U, Proksch B, Verleysdonk S, Ayturan M, Buniatian GH, Gleiter CH, Frey WH 2nd. (2009) Intranasal delivery of cells to the brain. Eur J Cell Biol. 88:315-324.

Dongsic Choi, Laura Montermini, Dae-Kyum Kim, Brian Meehan, Frederick P. Roth, Janusz Rak. (2018) The Impact of Oncogenic EGFRvIII on the Proteome of Extracellular Vesicles Released from Glioblastoma Cells. Molecular \& Cellular Proteomics. 17 (10) 1948-1964

El-Andaloussi S, Lee Y, Lakhal-Littleton S, Li J, Seow Y, Gardiner C, Alvarez-Erviti L, Sargent IL, Wood MJ. (2012) Exosome-mediated delivery of siRNA in vitro and in vivo. Nat Protoc. 7:2112-2126. 
Escobar Cabrera OE, Bongarzone ER, Soto EF, Pasquini JM. (1994) Single intracerebral injection of apotransferrin in young rats induces increased myelination. DevNeurosci. 16:248-54

Escobar Cabrera OE, Zakin MM, Soto EF, Pasquini JM. (1997) Single intracranial injection of apotransferrin in young rats increases the expression of specific myelin protein mRNA. J Neurosci Res. 47:603-8.

Espinosa de los Monteros A, de Vellis J. (1988) Myelin basic protein and transferrin characterize different subpopulations of oligodendrocytes in rat primary glial cultures. J Neurosci Res. 21:181-187.

Guardia Clausi M, Paez PM, Campagnoni AT, Pasquini LA, Pasquini JM. (2012) Intranasal administration of aTf protects and repairs the neonatal white matter after a cerebral hypoxic-ischemic event. Glia. 60(10):1540-54.

Guardia Clausi M, Pasquini LA, Soto EF, Pasquini JM. (2010) Apotransferrin-induced recovery after hypoxic/ischaemic injury on myelination. ASN Neuro. 19;2(5):e00048. doi: 10.1042/AN20100020.

György B, Módos K, Pállinger E, Pálóczi K, Pásztói M, Misják P, Deli MA, Sipos A, Szalai A, Voszka I, Polgár A, Tóth K, Csete M, Nagy G, Gay S, Falus A, Kittel A, Buzás EI. (2011) Detection and isolation of cell-derived microparticles are compromised by protein complexes resulting from shared biophysical parameters. Blood. 117(4):e39-48. doi: 10.1182/blood-2010-09-307595.20

György B, Szabó TG, Pásztói M, Pál Z, Misják P, Aradi B, László V, Pállinger E, Pap E, Kittel A, Nagy G, Falus A, Buzás EI. (2011) Membrane vesicles, current state-of-theart: emerging role of extracellular vesicles. Cell Mol Life Sci. 68:2667-88.

Haney, M. J., Klyachko, N. L., Zhao, Y., Gupta, R., Plotnikova, E. G., He, Z, Batrakova, E. V. (2015) Exosomes as drug delivery vehicles for Parkinson's disease therapy. Journal of controlled release. 207:18-30.

Harding C, Heuser J, Stahl P. (1983) Receptor-mediated endocytosis of transferrin and recycling of the transferrin receptor in rat reticulocytes. J Cell Biol. 97:329-39.

Harding, C., Heuser, J. and Stahl, P. (1984) Endocytosis and intracellular processing of transferrin and colloidal gold-transferrin in rat reticulocytes: demonstration of a pathway for receptor shedding. Eur. J. Cell Biol. 35:256.9. 
Hildonen S, Skarpen E, Halvorsen TG, Reubsaet L. (2016) Isolation and mass spectrometry analysis of urinary extra exosomal proteins. Sci Rep. 6:36331.

Hong CS, Funk S, Muller L, Boyiadzis M, Whiteside TLJ. (2016) Isolation of biologically active and morphologically intact exosomes from plasma of patients with cancer. Extracell Vesicles. 5:29289. doi: 10.3402/jev.v5.29289.

Joanna Kowal, Guillaume Arras, Marina Colombo, Mabel Jouve, Jakob Paul Morath, Bjarke Primdal-Bengtson, Florent Dingli, Damarys Loew, Mercedes Tkach, and Clotilde Théry. (2016) Proteomic comparison defines novel markers to characterize heterogeneous populations of extracellular vesicle subtypes. Proceedings of the National Academy of Sciences. 113:E968-E977.

Keri KC, Regner KR, Dall AT, Park F. (2018) Urinary exosomal expression of activator of G protein signaling 3 in polycystic kidney disease. BMC Res Notes. 11:359.19

Lai RC, Yeo RW, Tan KH, Lim SK. (2013) Exosomes for drug delivery -a novel application for the mesenchymal stem cell. Biotechnol Adv. 31:543-551.

Logozzi, M., De Milito, A., Lugini, L., Borghi, M., Calabrò, L., Spada, M., Fais, S. (2009). High levels of exosomes expressing CD63 and caveolin-1 in plasma of melanoma patients. PloS one. 4(4), e5219.

Long, Q., Upadhya, D., Hattiangady, B., Kim, D. K., An, S. Y., Shuai, B., Shetty, A. K. (2017). Intranasal MSC-derived A1-exosomes ease inflammation, and prevent abnormal neurogenesis and memory dysfunction after status epilepticus. Proceedings of the National Academy of Sciences of the United States of America. 114(17), E3536-E3545.

Luan, X., Sansanaphongpricha, K., Myers, I., Chen, H., Yuan, H., \& Sun, D. (2017). Engineering exosomes as refined biological nanoplatforms for drug delivery. Acta pharmacologica Sinica. 38(6), 754-763.

Marie-Pierre Caby, Danielle Lankar, Claude Vincendeau-Scherrer, Graça Raposo, Christian Bonnerot. (2005) Exosomal-like vesicles are present in human blood plasma. International Immunology. 17, 879-887.

Marimpietri, D., Petretto, A., Raffaghello, L., Pezzolo, A., Gagliani, C., Tacchetti, C., Pistoia, V. (2013) Proteome profiling of neuroblastoma-derived exosomes reveal the expression of proteins potentially involved in tumor progression. PloS one. 8(9), e75054. 
Marta CB, Escobar Cabrera OE, Garcia CI, Villar MJ, Pasquini JM, Soto EF. (2000) Oligodendroglial cell differentiation in rat brain is accelerated by the intracranial injection of apotransferrin. CellMolBiol. 46:529-39.

Mathieu M, Martin-Jaular L, Lavieu G, Théry C. (2011) Specificities of secretion and uptake of exosomes and other extracellular vesicles for cell-to-cellcommunication. Nat Cell Biol. 21:9-17.

McCarthy KD, de Vellis J. (1980) Preparation of separate astroglial and oligodendroglial cell cultures from rat cerebral tissue. J Cell Biol. 85(3):890-90222

Mellman, I. (1996) Endocytosis and molecular sorting. Annual review of cell and developmental biology. 12(1), 575-625.

Merkus FW, van den Berg MP. (2007) Can nasal drug delivery bypass the blood-brain barrier?: questioning the direct transport theory. Drugs R D. 8:133-144.

Paez PM, Marta CB, Moreno MB, Soto EF, Pasquini JM. (2002) Apotransferrin decreases migration and enhances differentiation of oligodendroglial progenitor cells in an in vitro system. DevNeurosci. 24:47-58.

Pan BT, Johnstone RM. (1983) Fate of the transferrin receptor during maturation of sheep reticulocytes in vitro: selective externalization of the receptor. Cell. 33:967-78.

Pan BT, Teng K, Wu C, Adam M, Johnstone RM. (1985) Electron microscopic evidence for externalization of the transferrin receptor in vesicular form in sheep reticulocytes. J Cell Biol. 101:942-8.

Pan, B. T., Teng, K., Wu, C., Adam, M., \& Johnstone, R. M. (1985). Electron microscopic evidence for externalization of the transferrin receptor in vesicular form in sheep reticulocytes. The Journal of cell biology. 101(3), 942-948.

Park, J.E.; Tan, H.S.; Datta, A.; Lai, R.C.; Zhang, H.; Meng, W.; Lim, S.K.; Sze, S.K. (2010) Hypoxic Tumor Cell Modulates Its Microenvironment to Enhance Angiogenic and Metastatic Potential by Secretion of Proteins and Exosomes. Mol Cell Proteom. 9:10851099.

Rajendran L, Bali J, Barr MM, Court FA, Krämer-Albers EM, Picou F, Raposo G, van der Vos KE, van Niel G, Wang J, Breakefield XO. (2014) Emerging roles of extracellular vesicles in the nervous system. JNeurosci. 34:15482-9.

Richter-Landsberg C, Heinrich M. (1996) OLN-93: a new permanent oligodendroglia cell line derived from primary rat brain glial cultures. J Neurosci Res. 45:161-173. 
Rosato-Siri MV, Badaracco ME, Ortiz EH, Belforte N, Clausi MG, Soto EF, Bernabeu R, Pasquini JM. (2010) Oligodendrogenesis in iron-deficient rats: effect of apotransferrin. JNeurosci Res. 88:1695-707.

Rufino-Ramos D, Albuquerque PR, Carmona V, Perfeito R, Nobre RJ, Pereira de Almeida L. (2017) Extracellular vesicles: Novel promising delivery systems for therapy of brain diseases. J Controlled Release. 262:247-258.

Sanz-Rubio D, Martin-Burriel I, Gil A, Cubero P, Forner M, Khalyfa A, Marin JM. (2018) Stability of Circulating Exosomal miRNAs in Healthy Subjects. Sci Rep. 8:10306.

Silvestroff L, Franco PG, Pasquini JM. (2012) ApoTransferrin: dual role on adult subventricular zone-derived neurospheres. PLoS One. 7(3):e33937.

Skog J, Würdinger T, van Rijn S, Meijer DH, Gainche L, Sena-Esteves M, Curry WT Jr, Carter BS, Krichevsky AM, Breakefield XO. (2008) Glioblastoma microvesicles transport RNA and proteins that promote tumour growth and provide diagnostic biomarkers. Nat Cell Biol. 10:1470-6. doi: 10.1038/ncb1800.

Soares Martins T, Catita J, Martins Rosa I, A B da Cruz E Silva O, Henriques AG. (2018) Exosome isolation from distinct biofluids using precipitation and column-based approaches. PLoSOne. doi: 10.1371/journal.pone.0198820.

Tan A, Rajadas J, Seifalian AM. (2013) Exosomes as theranostic delivery platforms for gene therapy. Adv Drug Deliv Rev. 65:357-367.

Taylor DD, Gercel-Taylor C.(2008) MicroRNA signatures of tumor-derived exosomes as diagnostic biomarkers of ovarian cancer. GynecolOncol. 110:13-21.

Théry C, Amigorena S, Raposo G, Clayton A. (2006) Isolation and characterization of exosomes from cell culture supernatants and biological fluids. Curr Protoc Cell Biol.; Chapter 3:Unit 3.22. doi: 10.1002/0471143030.cb0322s30.

Thorne RG, Frey WH. (2001) Delivery of neurotrophic factors to the central nervous system: pharmacokinetic considerations. Clin Pharmacokinet. 40:907-946.

Tore Skotland, Kirsten Sandvig, Alicia Llorente. (2017) Lipids in exosomes: Current knowledge and the way forward. Progress in Lipid Research. 66, 30-41.

Valadi H, Ekström K, Bossios A, Sjöstrand M, Lee JJ, Lötvall JO (2007). Exosome-mediated transfer of mRNAs and microRNAs is a novel mechanism of genetic exchange between cells. NatCell Biol. 6:654-9. 
Van der Pol E, Böing AN, Harrison P, Sturk A, Nieuwland R. (2012) Classification, functions, and clinical relevance of extracellular vesicles. Pharmacol Rev. 64:676-705.

Verity AN, Bredesen D, Vonderscher C, Handley VW, Campagnoni AT. (1983) Expression of myelin protein genes and other myelin components in an oligodendrocytic cell line conditionally immortalized with a temperature-sensitive retrovirus. $\mathrm{J}$ Neurochem.60(2):577-87.

Viktoriya Sokolova, Anna-Kristin Ludwig, Sandra Hornung, Olga Rotan, Peter A. Horn, Matthias Epple, Bernd Giebel. (2011) Characterisation of exosomes derived from human cells by nanoparticle tracking analysis and scanning electron microscopy. Colloids and Surfaces B: Biointerfaces 8:146-150.25.

Wang J, Pantopoulos K. (2011) Regulation of cellular iron metabolism. Biochem J. 434:365381.

Wubbolts R, Leckie RS, Veenhuizen PT, Schwarzmann G, Möbius W, HoernschemeyerJ, Slot JW, Geuze HJ, Stoorvogel W. (2003) Proteomic and biochemical analyses of human B cell-derived exosomes. Potential implications for their function and multivesicular body formation. J. Biol Che. 278:10963-72.

Zhang H, Yang B, Mu X, Ahmed SS, Su Q, He R, Wang H, Mueller C, Sena-Esteves M, Brown R, Xu Z, Gao G.(2011) Several rAAV vectors efficiently cross the blood-brain barrier and transduce neurons and astrocytes in the neonatal mouse central nervous system. Mol Ther. 8:1440-8. doi: 10.1038/mt.2011.98. .

Zhou Q, Li M, Wang X, Li Q, Wang T, Zhu Q et al (2011) Immune-related microRNAs are abundant in breast milk exosomes. Int J Biol Sci. 8(1):118-123.

Zhuang X, Xiang X, Grizzle W, Sun D, Zhang S, Axtell RC, Ju S, Mu J, Zhang L, Steinman L, Miller D, Zhang HG. (2011) Treatment of brain inflammatory diseases by delivering exosome encapsulated anti-inflammatory drugs from the nasal region to the brain. Mol Ther. 19:1769-1779. 


\section{Author contributions}

Pasquini, JM and Correale, $\mathbf{J}$ constructed the hypothesis of research.

Pasquini, JM; Correale, $\mathbf{J}$ and Mattera, VS planned methodology to reach the conclusions.

Mattera, VS; Pereyra Gerber, $\mathbf{P}$ and Verstraeten, SV organized, supervised the course of progress and took responsibility for research.

Pasquini, JM; Correale, J and Mattera, VS took responsibility for the collection of relevant biological materials, data management and reporting, execution of the experiments.

Pasquini, JM; Correale, J and Mattera, VS took responsibility for the logical interpretation and conclusion of results.

Pasquini, JM and Correale, $\mathbf{J}$ took responsibility for the literature review necessary for the study.

Pasquini, JM and Correale, $\mathbf{J}$ and Mattera VS took responsibility for writing the whole or important parts of the study.

Pereyra Gerber, P; Glisoni $R$ and Ostrowski, $M$ and Verstraeten, SV proof-read and scientifically reviewed the article before submission. 


\section{Figure legends}

Figure 1. Determination of the vesicular fraction in plasma samples and characterization of EV sources by immunoblotting. A) Protein absorbance measurements $(280 \mathrm{~nm})$ of each plasma sample. SEC fraction and immunoblot analysis of CD63 EV marker of each SEC fraction colocalizing with TfR1. B) Immunoblot analysis of CD63, Alix and CNX in EV samples, plasma and cell lysates. $n=3$ (independent plasma or conditioned media preparations).

Figure 2. Size distribution of different EV sources by DLS. Z-average size for particle suspension at $4{ }^{\circ} \mathrm{C}$ and $25^{\circ} \mathrm{C} . \mathrm{n}=2$ (independent plasma or conditioned media preparations). Results are presented as the mean of two independent experiments \pm standard deviation (SD). A) Human plasma EVs, B) mouse plasma EVs, C) N2a EVs, D) OLN-93 EVs, E) astrocyte primary culture EVs.

Figure 3. Morphological analysis of different EV sources by SEM. After ultracentrifugation, the pellets of all samples were resuspended in $50 \mu \mathrm{l}$ PFA 4\% during 15 minutes at $4^{\circ}$, washed with $1 \mathrm{ml}$ of MilliQ water and ultracentrifuged again at 100,000 x g $70 \mathrm{~min}$. The resulting pellet was resuspended in $50 \mu \mathrm{l}$ of Milli-Q wáter and, after metalized, Twenty $\mu \mathrm{L}$ of fresh samples were put on a silica substrate, dried, metalized and observed with a Zeiss Supra Electron microscope. $n=2$ (independent plasma or conditioned media preparations). Six fields were chosen randomly per $\mathrm{n}$, and EV size was determined calculating first the area of each individual EV to obtain the diameter. Results are presented as the mean of two independent experiments \pm standard deviation (SD). A) Human plasma EVs and frequency of sizes, B) mouse plasma EVs frequency of sizes, C) N2a EVs and frequency of sizes, D) OLN-93 EVs and frequency of sizes, E) astrocyte primary culture EVs and frequency of sizes. F) Average diameter from different EV sources. Scale bar: $100 \mathrm{~nm}$

Figure 4. TfR1 detection in different EV sources and passive loading of Tf by two loading strategies. A) Immunoblot analysis of TfR1 in different EV sources. B) Schematic representation of passive cargo loading of aTf into OLN-93 EVs. OLN93 cells were incubated in the presence of $100 \mu \mathrm{g} / \mathrm{mL}$ aTf for $30 \mathrm{~min}$ at $37^{\circ} \mathrm{C}$. After incubation, EVs were isolated by differential centrifugation and ultracentrifugation and aTf incorporation was verified by Western blot. C) Passive ex-vivo loading of aTf into human plasma EVs. (1) EVs isolated from $2 \mathrm{~mL}$ of 
human plasma by SEC were incubated with $100 \mu \mathrm{g} / \mathrm{mL}$ of aTf overnight at room temperature and loading efficiency was evaluated by Western blot. (2) EVs isolated from $2 \mathrm{~mL}$ of human plasma by SEC were incubated with $100 \mu \mathrm{g} / \mathrm{mL}$ of Tf-TR overnight in agitation at room temperature. Ratio was calculated by using RFU values: EVs-Tf ratio: EV-Tf/(Tf+UC1-2). n = 4 (independent plasma preparations). Comparisons were performed using Student's $t$ test (*P < $0.05 ; * * \mathrm{P}<0.01 ; * * * \mathrm{P}<0.001 * * * * \mathrm{p}<<0,0001)$. Results are presented as the mean of at least three independent experiments \pm standard error of the mean (SEM).

Figure 5. Tf binding competition assays. A) Schematic representation of Competition assay I: equal masses of EVs were incubated with PBS or PBS $+100 \mu \mathrm{g} / \mu \mathrm{lf}-\mathrm{TR}$ overnight in agitation at room temperature. The next day, samples were washed and ultracentrifuged in order to wash the remaining non-bound fluorescent $\mathrm{Tf}$ and the pellets were then incubated with non-fluorescent $400 \mu \mathrm{g} / \mu \mathrm{l}$ aTf in order to evaluate the displacement of fluorescent protein binding. Incubation and isolation conditions were those described above. Finally, the pellets obtained were resuspended in $20 \mu \mathrm{l}$ RIPA buffer and samples were analyzed by fluorometry. B) Ratio was calculated by using RFU's values: EVs-Tf ratio: EV-Tf/(Tf+UC1-2). $\mathrm{n}=4$ (independent plasma preparations). Comparisons were performed using Student's t test $(* \mathrm{P}<0.05 ; * * \mathrm{P}<0.01 ; * * * \mathrm{P}<$ $0.001 * * * * \mathrm{p}<<0,0001)$. Results are presented as the mean of at least three independent experiments \pm standard error of the mean (SEM). C) Schematic representation of Competition assay II: EVs were incubated with with non-labeled Tf in its native conformation and denatured $\mathrm{Tf}$ at a saturating concentration $(400 \mu \mathrm{g} / \mathrm{mL})$ and then incubated with a 4-time lower concentration of Tf-TR with $(100 \mu \mathrm{g} / \mathrm{mL})$. Procedures were the same as in A). $\mathrm{n}=4$ (independent plasma preparations). Comparisons were performed using one way ANOVA followed by Bonferroni post hoc test $(* \mathrm{P}<0.05$; $* * \mathrm{P}<0.01$; $* * * \mathrm{P}<0.001)$. E) Ligand-receptor binding assay using different amounts of EVs $(30,60,90$ and $120 \mu \mathrm{g})$ and $100 \mu \mathrm{g} / \mathrm{mL}$ of Tf-TR. $\mathrm{n}=4$ (independent plasma preparations). F) Ligand-receptor binding assay using different amounts of Tf-TR $(10,20,100,200 \mathrm{ug} / \mathrm{mL})$ and $60 \mathrm{ug}$ of EVs per condition. $\mathrm{n}=4$ (independent plasma preparations). 
Table I. EVs yield from human and mouse plasma, OLN93 and N2a cell lines and astrocyte primary cultures.

\begin{tabular}{|c|c|c|c|c|}
\hline EVs Source & HEK & N2a & OLN-93 & $\begin{array}{c}\text { Astrocyte primary } \\
\text { culture }\end{array}$ \\
\hline $\begin{array}{l}\text { Cellular density } \\
\text { (cells/mL of } \mathrm{CM} \text { ) }\end{array}$ & 5.105 cells $/ \mathrm{mL}$ & 6,2.105 cells $/ \mathrm{mL}$ & 6,2.105 cells $/ \mathrm{mL}$ & $2,0.105$ cells $/ \mathrm{mL}$ \\
\hline Conditioned medium volume & $40 \mathrm{~mL}$ & $40 \mathrm{~mL}$ & $80 \mathrm{~mL}$ & $80 \mathrm{~mL}$ \\
\hline Protein Concentration & $1-4 \mu \mathrm{g} / \mu \mathrm{L}$ & $1-2 \mu \mathrm{g} / \mu \mathrm{L}$ & $1-2.5 \mu \mathrm{g} / \mathrm{mL}$ & $0,5-0.7 \mu \mathrm{g} / \mu \mathrm{L}$ \\
\hline \multirow{3}{*}{$\begin{array}{l}\text { Total Protein in RIPA's } \\
\text { resuspension volume }\end{array}$} & $160 \mu \mathrm{g}$ & $60-100 \mu \mathrm{g}$ & $60-150 \mu \mathrm{g}$ & $25 \mu \mathrm{g}$ \\
\hline & EVs Source & Human plasma & Mouse plasma & \\
\hline & Plasma volume & $4 \mathrm{~mL}$ & $4 \mathrm{~mL}$ & \\
\hline & $\begin{array}{c}\text { Protein } \\
\text { concentration }\end{array}$ & $1-2 \mu \mathrm{g} / \mu \mathrm{L}$ & $1-3 \mu \mathrm{g} / \mu \mathrm{L}$ & \\
\hline & Total protein in & & & \\
\hline & $\begin{array}{c}\text { RIPA's resuspension } \\
\text { volume }\end{array}$ & $120 \mu \mathrm{g}$ & $150 \mu \mathrm{g}$ & \\
\hline
\end{tabular}


Table II. Dynamic light scattering (DLS) of EVs derived from human and mouse plasma (Hp and Mp), OLN93 and N2a cell lines and astrocyte primary cultures performed at $4{ }^{\circ} \mathrm{C}$ and 25 ${ }^{\circ} \mathrm{C}$.

\begin{tabular}{|c|c|c|c|c|c|c|c|}
\hline \multirow[b]{2}{*}{ EV source } & \multirow[b]{2}{*}{$\begin{array}{l}\text { Temp. } \\
\left({ }^{\circ} \mathbf{C}\right)\end{array}$} & \multirow[b]{2}{*}{$\begin{array}{c}\text { Z-average } \\
\text { (nm) }\end{array}$} & \multicolumn{4}{|c|}{$\mathrm{D}_{h}(\mathrm{~nm})$} & \multirow{2}{*}{$\begin{array}{c}\text { PDI } \\
( \pm \text { S.D. })\end{array}$} \\
\hline & & & $\begin{array}{c}\text { Peak 1* } \\
(\text { nm) }( \pm \text { S.D. })\end{array}$ & $\begin{array}{c}\text { \% Intensity } \\
( \pm \text { S.D. })\end{array}$ & $\begin{array}{c}\text { Peak 2** } \\
(\text { nm) }( \pm \text { S.D. })\end{array}$ & $\begin{array}{c}\text { \% Intensity } \\
( \pm \text { S.D. })\end{array}$ & \\
\hline \multirow[t]{2}{*}{ Hр } & 4 & $115(7)$ & 163 (19) & $100(0)$ & -- & -- & $0.240(0.027)$ \\
\hline & 25 & $161(7)$ & $179(5)$ & $100(0)$ & -- & -- & $0.299(0.038)$ \\
\hline \multirow{2}{*}{ Mp } & 4 & $190(4)$ & $192(6)$ & $100(0)$ & -- & -- & $0.238(0.022)$ \\
\hline & 25 & $200(5)$ & $208(11)$ & $100(0)$ & -- & -- & $0.248(0.013)$ \\
\hline \multirow{2}{*}{ N2a } & 4 & $157(14)$ & 167 (24) & $100(0)$ & -- & -- & $0.287(0.045)$ \\
\hline & 25 & $202(4)$ & $239(52)$ & $100(0)$ & -- & -- & $0.381(0.028)$ \\
\hline \multirow{2}{*}{ OLN-93 } & 4 & $166(9)$ & $182(19)$ & $100(0)$ & -- & -- & $0.269(0.063)$ \\
\hline & 25 & $180(5)$ & $196(7)$ & $100(0)$ & -- & -- & $0.237(0.020)$ \\
\hline \multirow{2}{*}{$\begin{array}{c}\text { Astrocyte } \\
\text { primary culture }\end{array}$} & 4 & $211(14)$ & $256(22)$ & $100(0)$ & -- & -- & $0.331(0.049)$ \\
\hline & 25 & 374 (84) & $362(25)$ & $66(12)$ & 107 (19) & $34(12)$ & $0.554(0.030)$ \\
\hline
\end{tabular}

*Major population

**Minor population 
Table III. Bibliographic compilation from Exocarta's database containing sources, species and reference of vesicles containing $\mathrm{T} f \mathrm{R} 1$ and our contribution in this paper.

\section{Homo sapiens Mus musculus Rattus norvegicus}

\begin{tabular}{|c|c|c|c|c|c|c|c|}
\hline $\begin{array}{c}\text { Gene } \\
\text { Symbol/ } \\
\text { Protein }\end{array}$ & $\begin{array}{l}\text { Vesicle } \\
\text { Source }\end{array}$ & $\begin{array}{l}\text { Vesicle } \\
\text { Type }\end{array}$ & $\begin{array}{c}\text { Vesiclepedia } \\
\text { Reference }\end{array}$ & $\begin{array}{c}\text { Vesicle } \\
\text { Type }\end{array}$ & $\begin{array}{c}\text { Vesiclepedia } \\
\text { Reference }\end{array}$ & $\begin{array}{c}\text { Vesicle } \\
\text { Type }\end{array}$ & $\begin{array}{c}\text { Vesiclepedia } \\
\text { Reference }\end{array}$ \\
\hline \multirow[t]{5}{*}{ CD71/TfR1 } & \multirow[t]{5}{*}{ Plasma } & Exosome & 15908444 & $\begin{array}{c}\text { Exosom } \\
\text { e }\end{array}$ & 22046311 & - & - \\
\hline & & Exosome & 24115447 & EVs & This study & - & - \\
\hline & & Microsome & 21049385 & & & & \\
\hline & & Microsome & 23056467 & & & & \\
\hline & & EVs & This study & & & & \\
\hline & Neuroblastoma & $\begin{array}{l}\text { Exosome/ } \\
\text { Membrane } \\
\text { vesicle }\end{array}$ & 24069378 & EVs & This study & - & - \\
\hline & $\begin{array}{l}\text { Oligodendro- } \\
\text { glioma }\end{array}$ & - & - & - & - & EVs & This study \\
\hline & Astrocytes & $\begin{array}{c}\text { Astrocynoma } \\
\text { cells EVs }\end{array}$ & 30006486 & - & - & EVs & This study \\
\hline
\end{tabular}


Table IV. Z-average size, hydrodynamic diameter $\left(\mathrm{D}_{h}\right)$, size distribution $(\mathrm{PDI})$ and Z-potential of Tf-free

$(\mathrm{HpEV})$ and Tf-loaded EVs (Hp/Tf EV) derived from human plasma (Hp) performed at $25^{\circ} \mathrm{C}$ by DLS.

\begin{tabular}{|c|c|c|c|c|c|c|c|}
\hline \multirow{2}{*}{ EV source } & \multirow{2}{*}{$\begin{array}{c}\text { Z-average } \\
\text { (nm) }\end{array}$} & \multicolumn{4}{|c|}{$\mathbf{D}_{h}(\mathbf{n m})$} & \multirow{2}{*}{$\begin{array}{c}\text { PDI } \\
\text { ( } \pm \text { S.D.) }\end{array}$} & \multirow[b]{2}{*}{$\begin{array}{c}\text { Z-potentia } \\
(\mathbf{m V})\end{array}$} \\
\hline & & $\begin{array}{c}\text { Peak 1* } \\
\text { (nm) ( } \pm \text { S.D.) }\end{array}$ & $\begin{array}{c}\text { \% Intensity } \\
\text { (土S.D.) }\end{array}$ & $\begin{array}{c}\text { Peak } 2 * * \\
(\mathrm{~nm})( \pm \text { S.D. })\end{array}$ & $\begin{array}{c}\text { \% Intensity } \\
\text { (土S.D.) }\end{array}$ & & \\
\hline HpEV & $161(7)$ & $179(5)$ & $100(0)$ & -- & -- & $0.299(0.038)$ & $-27(4)$ \\
\hline Hp/Tf EV & $267(4)$ & $253(53)$ & $89(4)$ & $43(18)$ & $11(4)$ & $0.427(0.065)$ & $-36(2)$ \\
\hline
\end{tabular}


A
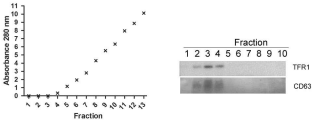

8

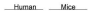

N2a OLY-93 datrogytes
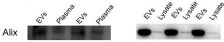

?

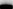

Alix

CD63

$-\quad-\mathrm{CNX}$ 
B) (a)
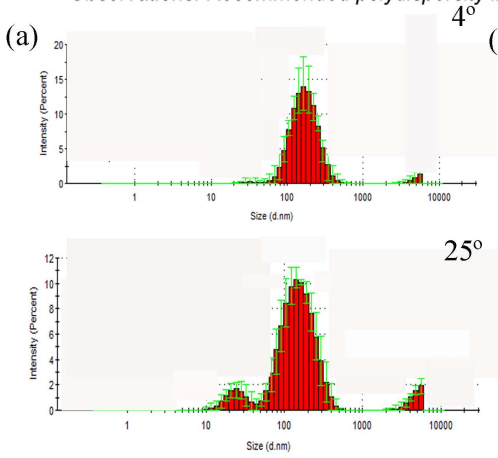

(d) (b)

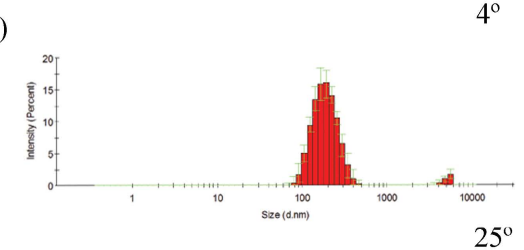

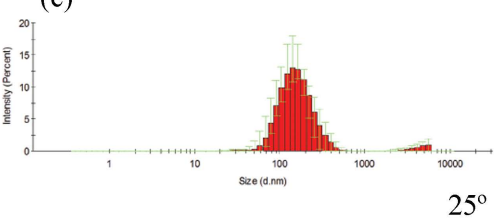
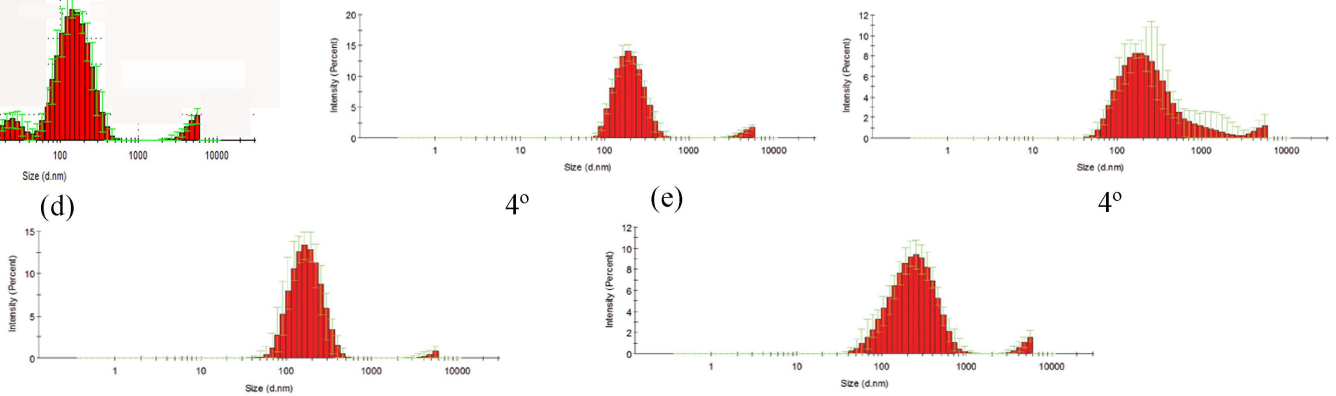

$25^{\circ}$

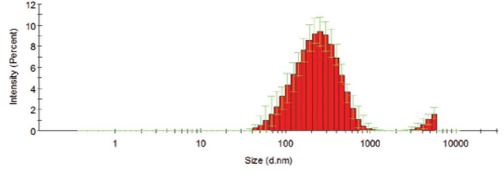

$25^{\circ}$
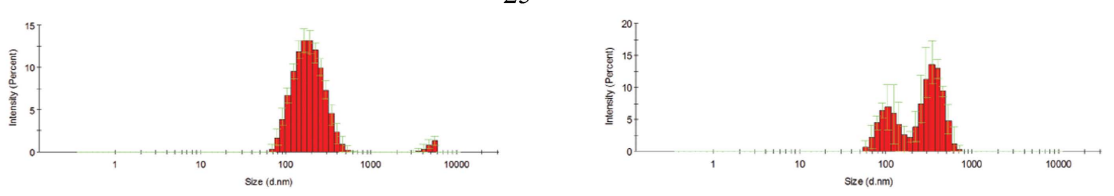


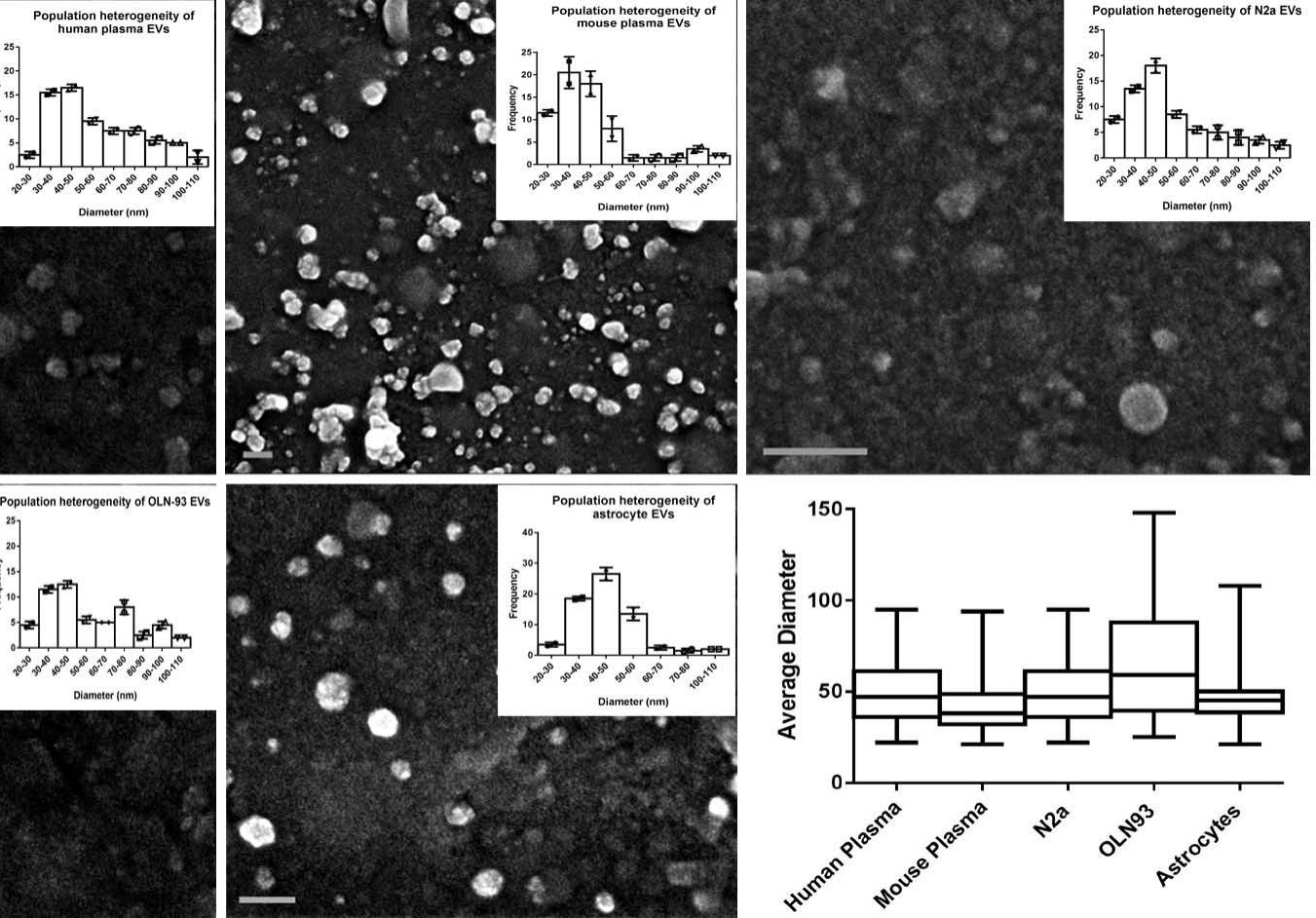


A

Anas knea:

rnt

Rau we

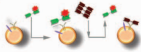

D-

B
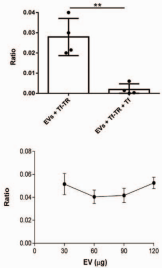

C

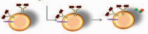

vic.

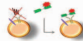

t.t.
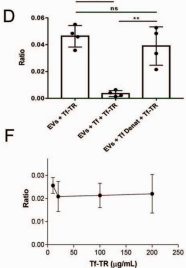